\title{
HUBUNGAN PERHATIAN ORANG TUA TERHADAP PENINGKATAN MORAL ANAK
}

\author{
Ulfa Hidayatus Sholikah \\ Fakultas Ushuluddin Adab dan Dakwah IAIN Ponorogo \\ hidayasholikah@gmail.com \\ Mayrina Eka Prasetyo Budi \\ Fakultas Ushuluddin Adab dan Dakwah IAIN Ponorogo \\ mayrinaekapb@gmail.com
}

\begin{abstract}
This study aims to determine the level of parental attention to children aged 7-12 years in Durenan Village, Sidorejo Magetan District, for Knowing the level of moral development in children aged 7-12 years in Durenan Village, Sidorejo Magetan District, and to find out the relationship between parents' attention to improving the morale of children aged 7-12 years in Durenan Village, Sidorejo Magetan District. This study uses a quantitative approach with correlational research. The data collection technique uses questionnaire and observation techniques. The research data were analyzed using product moment correlation. The results showed the level of parental attention in the category moderate with a percentage of $87.5 \%$, the level of moral development of children is in the medium category with a percentage of $78.13 \%$, and there is a significant relationship between parental attention and moral improvement of children aged 7-12 years in Durenan Village, Sidorejo Magetan District. It is known from the results of calculations using the SPSs, namely the count of 0.929 and $r$ table of 0.349, so that Ha accepted Ho is rejected, which means that there is a significant relationship between parental attention and moral improvement of children aged 7-12 years in Durenan Village, Sidorejo Magetan District.
\end{abstract}

Keywords: parents' attention, children's moral improvement

\begin{abstract}
Abstrak
Kajian penelitian ini bertujuan untuk mengetahui tingkat perhatian orang tua terhadap anak usia 7-12 tahun di Desa Durenan Kecamatan Sidorejo Magetan, untuk mengetahui tingkat perkembangan moral pada anak usia 7-12 tahun di Desa Durenan Kecamatan Sidorejo Magetan, dan untuk mengetahui hubungan perhatian orang tua terhadap peningkatan moral anak usia 7-12 tahun di Desa Durenan Kecamatan Sidorejo Magetan. Penelitian ini menggunakan pendekatan kuantitatif dengan jenis penelitian korelasional. Teknik pengumpulan data menggunakan teknik kuisioner dan observasi. Data
\end{abstract}


penelitian dianalisis menggunakan korelasi product moment. Hasil penelitian menunjukkan tingkat perhatian orang tua dalam kategori sedang dengan presentase $87,5 \%$, tingkat perkembangan moral anak dengan kategori sedang dengan presentase $78,13 \%$, dan terdapat hubungan yang signifikan antara perhatian orang tua dan peningkatan moral anak usia 7-12 tahun di Desa Durenan Kecamatan Sidorejo Magetan. Hal ini diketahui dari hasil perhitungan menggunakan spss yaitu $r$ hitung sebesar 0,929 dan $r$ tabel sebesar 0,349, sehingga Ha diterima Ho ditolak yang artinya terdapat hubungan yang signifikan antara perhatian orang tua dan peningkatan moral anak usia 7-12 tahun di Desa Durenan Kecamatan Sidorejo Magetan.

\section{Kata Kunci: perhatian orang tua, peningkatan moral anak}

\section{PENDAHULUAN}

Perhatian orang tua dalam mendidik keluarga memiliki peran penting dalam proses perkembangan moral anak. Orang tua yang memberikan perhatian serius dalam mendidik akan menjadikan anak memiliki nilai-nilai moral yang baik, sehingga anak akan mampu menghindar dari berbagai pengaruh negatif dari kemajuan teknologi dan media informasi. Kurangnya perhatian orang tua dalam mendidik, maka akan menjadikan anak mudah terpengaruh hal yang negatif. Masalah moral menjadi masalah yang mengkhawatirkan semua orang, terlebih khusus para orang tua, namun banyak orang tua yang belum menyadari bahwasanya pendidikan moral diperoleh pertama kali dari orang tua. Orang tua adalah pendidik pertama dan utama bagi anak. Orang tua seharusnya menjadi contoh yang baik bagi anaknya, karena anak meniru orang terdekatnya. Sebagian besar orang tua sering mencari kambing hitam dari perilaku negatif anak, padahal anak sesungguhnya meniru orang tuanya baik dalam berpikir maupun bertingkah laku.

Ada beberapa penelitian sebelumnya yang membahas peran orang tua dan perkembangan moral yaitu Pertama, Penelitian yang dilakukan oleh Siti Rahayu yang berjudul "Peran Orang Tua Terhadap Pendidikan Moral Remaja di Dusun Mendak Buntar Mojogedang Karanganyar”. Penelitian tersebut menghasilkan kesimpulan yaitu orang tua memiliki peran penting dalam pembinaan pendidikan moral pada remaja. Kedua, Penelitian yang dilakukanIra Nur Afifah Sari yang berjudul "Hubungan Antara Pola Asuh Orang Tua Dengan Perkembangan Moral Anak di Kelompok B TK Aisyiyah 1 Hadiluwih, Sragen". Penelitian tersebut menghasilkan kesimpulan terdapat hubungan 
antara pola asuh orang tua dengan perkembangan moral anak kelompok B di TK Aisyiyah 1 Hadiluwih Sragen. Dibuktikan dengan hasil nilai r (pearson correlation) sebesar 0,511. Dengan taraf kesalahan signifikan sebesar 0,001<0,01 dan nilai $r$ hitung sebesar 0,511 nilai $r$ tabel sebesar 0,312 $(0,511>0,312)$. Yang berarti Ho ditolak dan Ha diterima.

Perhatian orang tua dan perkembangan moral menjadi topik menarik untuk selalu dikaji dan diteliti di semua tempat, termasuk di Desa Durenan Kecamatan Sidorejo Kabupaten Magetan. Wilayah tersebut berada di lereng Gunung Lawu. Masyarakatnya bermata pencaharian sebagai petani, pedagang, wiraswasta, pegawai negeri maupun swasta. Perbedaan profesi tentunya menyebabkan perbedaan perhatian masyarakat sebagai orang tua dalam mendidik anak. Adanya perbedaan perhatian menyebabkan adanya perbedaan pengusaan nilai- nilai moral anak, baik di lingkungan tempat tinggal atau di sekolah.

Penelitian ini dilakukan guna mengetahui tingkat perhatian orang tua terhadap anak usia 7-12 tahun di Desa Durenan Kecamatan Sidorejo Magetan, tingkat perkembangan moral pada anak usia 7-12 tahun di Desa Durenan Kecamatan Sidorejo Magetan, hubungan perhatian orang tua terhadap peningkatan moral anak usia 7-12 tahun di Desa Durenan Kecamatan Sidorejo Magetan. Ada dua hipotesa penelitian yaitu, Ho: Tidak terdapat hubungan perhatian orang tua terhadap peningkatan moral anak usia 7-12 tahun di Desa Durenan Kecamatan Sidorejo Magetan. Ha: Terdapat hubungan perhatian orang tua terhadap peningkatan moral anak usia 7-12 tahun di Desa Durenan Kecamatan Sidorejo Magetan.

\section{METODE PENELITIAN}

Penelitian ini menggunakan metode penelitian kuantitatif. Terdapat dua variabel, yaitu variabel independen (perhatian orang tua/X), dan variabel dependen (peningkatan moral anak/Y). Populasi berjumlah 32 orang tua dari anak usia 7-12 tahun di Desa Durenan Kecamatan Sidorejo Magetan. Sampel yang digunakan adalah sampel jenuh yaitu melibatkan semua populasi. Teknik pengumpulan data menggunakan instrumen kuesioner dan observasi. Instrumen penelitian menggunakan kuesioner yang dibuat sesuai skala guttman. Nilai skor "1" untuk jawaban "Ya" dan " 0 " untuk jawaban 
"tidak". ' Alat mengolah data menggunakan aplikasi IBM SPSS Statistics V21. SPSS merupakan aplikasi program komputer yang dibuat untuk mengolah data dengan menggunakan metode statistik tertentu. ${ }^{2}$ Teknik analisis data menggunakan statistik parametis. $^{3}$

1. Uji Validitas Instrumen

Uji validasi menggunakan validitas isi dengan mencermati kisi- kisi atau indikator instrumen. Dalam kisi- kisi atau indikator instrumen terdapat variabel penelitian, indikator penelitian, dan nomor item pernyataan. Instrumen tersebut selanjutnya diuji coba dengan menghitung korelasi (product moment) antara skor butir instrumen dengan skor total. ${ }^{4}$ Uji ini dilakukan dengan cara membandingkan angka $\mathrm{r}$ hitung dan $\mathrm{r}$ 0,3. Jika $R x y \geq r$ 0,3, maka kesimpulannya item kuesioner tersebut valid. Apabila $R x y \leq r$ 0,3 , maka kesimpulannya item kuesioner tersebut tidak valid. ${ }^{5}$

Setelah data variabel $\mathrm{X}$ diolah menggunakan aplikasi spss yaitu hasil perbandingan dari $r$ hitung dengan $r$ tabel. $R$ tabel diperoleh dari $\mathrm{db}=\mathrm{n}-2=32-2=30$, lalu dikonsultasikan dengan tabel nilai " $\mathrm{r}$ " product moment. ${ }^{6} \mathrm{Jadi}, \mathrm{r}$ tabel dengan taraf signifikan $5 \%$ adalah 0,349 . Setelah dibandingkan antara $r$ hitung dengan $r$ tabel diperoleh 36 item valid dan 23 item tidak valid. Item yang tidak valid akhirnya dibuang dan tidak digunakan. Adapun untuk variabel $Y$ juga sama, dibandingkan antara $r$ hitung dengan $r$ tabel. $\mathrm{R}$ tabel diperoleh dari $\mathrm{db}=\mathrm{n}-2=32-2=30$, lalu dikonsultasikan dengan tabel nilai "r" product moment. ${ }^{7}$ Jadi, $\mathrm{r}$ tabel dengan taraf signifiksn $5 \%$ adalah 0,349 . Setelah dibandingkan diperoleh 26 item valid, dan 1 item tidak valid. Item yang tidak valid dibuang dan tidak digunakan.

1. Uji Reliabilitas Instrumen

Uji reliabilitas menggunakan rumus alpha cronbach, dasar pengambilan keputusan dalam uji reliabilitas adalah sebagai berikut: ${ }^{8}$ Jika nilai dari alpha cronbach $\geq 0,60$ maka instrumen dinyatakan reliabel atau konsisten. Jika nilai dari alpha

${ }^{1}$ Sugiono, Metode Penelitian Kuantitatif, Kualitatif, dan R\&D (Bandung: Alfabeta, 2016), 96.

${ }^{2}$ Singgih Santoso, Panduan Lengkap SPSS Versi 23 (Jakarta: PT Alex Media Komputindo, 2016),

11.

${ }^{3}$ Ibid., 150.

${ }^{4}$ Ibid., 129.

${ }^{5}$ Ibid., 126.

${ }^{6}$ Retno Widyaningrum, Statistika (Yogjakarta: Pustaka Felicha, 2016), 115.

${ }^{7}$ Ibid., 115.

${ }^{8}$ V. Wiratna Sujarweni, SPSS Untuk Penelitian (Yogjakarta: Pustaka Baru, 2014), 193. 
cronbach $\leq$ 0,60 maka instrumen dinyatakan tidak reliabel atau tidak konsisten. Hasilnya adalah nilai koefisien alpha cronbach yaitu 0,891 pada variabel X (perhatian orang tua) dan 0,858 pada variable Y (peningkatan moral anak). Masing- masing no item $\geq 0,60$, maka dapat dikatan bahwa masing- masing item pada instrumen dinyatakan reliabel atau konsisten.

\section{HASIL PENELITIAN DAN PEMBAHASAN}

Berikut adalah hasil uji normalitas, uji linieritas dan uji hipotesa.

1. Uji Normalitas

Uji normalitas untuk mengetahui sebaran distribusi data menggunakan rumus Kolmogorof-smirnov. Distribusi data dikatakan normal jika nilai signifikan $\geq 0,05$, dan sebaliknya jika nilai signifikan $\leq 0,05$ maka distribusi data dinyatakan tidak normal. Hasil output SPSS diketahui bahwa nilai Asymp. Sig. (2-tailed) nya adalah 0,020. Nilai signifikansi data tersebut berada di atas 0,05, sehingga dapat dinyatakan bahwa data tersebut berdistribusi normal.

2. Uji Linieritas

Uji linieritas untuk mengetahui apakah antar variabel mempunyai hubungan yang linier atau tidak secara signifikan. Jika nilai sig $\geq 0,05$ maka hubungan antar variabel adalah linier, jika nilai sig $\leq 0,05$, maka hubungan antar variabel adalah tidak linier. Hasil output SPSS nilai Sig. deviation from linearity sebesar 0,485. Nilai signifikansi ini berada di atas 0,05, sehingga dapat disimpulkan terdapat hubungan yang linier antara perhatian orang tua terhadap peningkatan moral anak.

3. Uji Hipotesis

Uji hipotesis menggunakan korelasi product moment. Jika $\mathrm{r}$ hitung $\geq \mathrm{r}$ tabel, maka Ha diterima dan Ho ditolak, yang artinya terdapat hubungan signifikan. Jika $r$ hitung $\leq r$ tabel, maka Ha ditolak dan Ho diterima, yang artinya tidak ada hubungan yang signifikan. Dari hasil output SPSS hasil uji hipotesis menggunakan korelasi product moment diperoleh hasil $\mathrm{r}$ hitung sebesar 0,929 dengan signifikasi sebesar 0,000. Dengan taraf kepercayaan 0,05 atau 5\%, diperoleh $r$ tabel sebesar 0,349. Sehingga $r$ hitung $\geq r$ tabel yaitu $0,929 \geq 0,349$, maka Ha diterima dan Ho ditolak yang berarti terdapat hubungan yang signifikan antara perhatian orang tua terhadap peningkatan moral anak usia 7-12 tahun di Desa Durenan Sidorejo Magetan. 
1. Perhatian orang tua anak usia 7-12 tahun di Desa Durenan Kecamatan Sidorejo Magetan

Berdasarkan hasil analisis yang telah dilakukan diketahui bahwa terdapat dua tingkat kriteria pada perhatian orang tua yaitu pada tingkat sedang dan rendah. Kriteria ini didapatkan dari hasil pengolahan data statistika dengan klasifikasi menggunakan norma standar deviasi. Hal ini dapat diketahui dari keseluruhan terdapat 32 orang tua anak usia 7-12 tahun, 28 diantaranya memiliki persentasi 87,5 \% berada pada kategori sedang dan 4 orang memiliki persentase $12,5 \%$ berada pada ketegori rendah. Hasil persentasi tersebut menunjukkan bahwa sebagian besar dari orang tua anak usia 7-12 tahun memiliki tingkat perhatian terhadap anak sedang.

Tingkat perhatian yang sedang, menunjukkan bahwa orang tua anak usia 7-12 tahun cukup mampu menerapkan bentuk- bentuk perhatian kepada anak. Bentukbentuk perhatian tersebut meliputi memberikan hadiah dan hukuman, mengarahkan dan membimbing, memberikan contoh baik, pembiasaan sehari-hari, dialog, keteladanan, empati dan menciptakan suasana terbuka. ${ }^{9}$ Selain dengan menerapkan bentuk perhatian, orang tua juga lebih memprioritaskan anak disela kesibukan pekerjaannya. Tingkat perhatian orang tua yang rendah disebabkan karena kurang pedulinya orang tua terhadap anak. Orang tua lebih mementingkan kepentingannya, bekerja misalnya, tanpa memperhatikan kepentingan anak. Faktor penyebab lainnya adalah karena awamnya pengetahuan orang tua dalam hal mendidik anak, sehingga anak dibiarkan berkembang dengan sedikit pengawasan dari orang tua. 
Penjelasan diatas sesuai dengan pendapat Kartini Kartono sebagaimana yang dikutip oleh Romlah, perhatian adalah reaksi umum dari organism dan kesadaran yang menyebabkan bertambahnya aktivitas, konsentrasi serta pembatasan kesadaran terhadap suatu objek. ${ }^{10}$ Objek perhatian orang tua adalah anak, sehingga perhatian orang tua terhadap adalah dengan meningkatkan konsentrasi serta perbatasan kesadaran terhadap anak serta memberikan bentuk- bentuk perhatian kepada anak dengan penuh ketulusan dan kasih sayang, sehingga akan membentuk kepribadian anak yang lebih baik.

2. Peningkatan Moral Anak Usia 7-12 Tahun di Desa Durenan Kecamatan Sidorejo Magetan

Berdasarkan hasil analisis yang telah dilakukan diketahui bahwa terdapat tiga tingkat kriteria pada perkembangan moral anak yaitu pada tingkat tinggi, sedang dan rendah. Kriteria ini didapatkan dari hasil pengolahan data statistika dengan klasifikasi menggunakan norma standart deviasi. Hal ini dapat diketahui dari keseluruhan terdapat 32 orang tua anak usia 7-12 tahun, 3 diantaranya memiliki persentasi 9,37\% berada pada karegori tinggi, 25 orang memiliki persentase 78,13\% berada pada ketegori sedang dan 4 orang memiliki persentase $12,5 \%$ pada kategori rendah. Hasil presentasi tersebut menunjukkan bahwa sebagian besar anak usia 7-12 tahun memiliki tingkat perkembangan moral yang sedang. Peningkatan moral yang sedang menunjukkan bahwa anak usia 7-12 tahun cukup mampu menerapkan nilai- nilai moral dan memilih teladan dan sesuatu mana yang baik dan buruk.

Terdapat tiga anak memiliki kategori tinggi dalam proses peningkatan moral. Menunjukkan bahwa anak usia 7- 12 tahun ini telah mampu menerapkan nilai- nilai 
moral pada kehidupannya, telah mampu mengidentifikasi tingkah laku seseorang dengan mengambil hal positif, dan mampu mengembangkan dalam kehidupan sehariharinya secara baik. Anak telah mampu memandang masalahnya dari berbagai sudut dan mampu menyelesaikannya dengan mengambil berbagai faktor sebagai bahan pertimbangan. ${ }^{11}$ Tentu tidak luput dengan perhatian orang tua yang baik dan mendukung dan mendampingi dalam bekembangnya moral anak. Sebagian besar peningkatan moral anak pada kategori sedang, hal ini menunjukkan bahwa anak sudah cukup mampu mengenal baik buruk, benar salah. Mampu memandang suatu perbuatan yang baik adalah ketika telah diterima oleh banyak orang dan dapat memelihara ketertiban sosial. ${ }^{12}$ Bagi anak yang memiliki kategori rendah disebabkan karena perkembangan intelektual anak belum dapat mempelajari prinsip- prinsip abstrak, benar salah. Anak hanya belajar bagaimana bertindak tanpa mengetahui alasannya. ${ }^{13}$

Penjelasan diatas sesuai dengan pendapat bahwa moral atau moralitas ini dilandasi dengan nilai- nilai tertentu yang diyakini oleh seseorang tertentu sebagai sesuatu yang baik atau buruk, sehingga pada akhirnya dapat membedakan mana yang patut dilakukan dan perkara mana yang harus ditinggalkan. ${ }^{14}$ Cara peningkatan moral antara lain melalui pendidikan langsung, identifikasi dan proses coba- coba. Terdapat tiga tingkat tahapan peningkatan moral yaitu pra konvensional, konvensional, dan pasca konvensional. $^{15}$

3. Hubungan Perhatian Orang Tua Terhadap Peningkatan Moral Anak Usia 7-12 Tahun

\footnotetext{
${ }^{11}$ Elizabeth B Hurlock, Psiklogi Perkembangan (Jakarta, Erlangga: 1991), 225.

${ }^{12}$ Ibid., 163.

${ }^{13}$ Ibid., 123.

${ }^{14}$ Juntika Nurichsan dan Mubiar Agustin, Dinamika Perkembangan Anak dan Remaja: tinjau Psikologi, Pendidikan dan Bimbingan (Bandung: PT Refika Aditama, 2016), 54.

${ }^{15}$ Elizabeth B Hurlock, Psiklogi Perkembangan (Jakarta, Erlangga: 1991), 123.
} 
Hasil analisis korelasi product moment yang telah dilakukan, diketahui bahwa terdapat hubungan yang signifikan antara perhatian orang tua dan peningkatan moral anak usia 7-12 tahun di Desa Durenan Kecamatan Sidorejo Magetan. Anak yang merasakan ada keutuhan di dalam keluarga dapat melahirkan pemahaman terhadap dunia keorangtuaan, orang tua yang berperilaku taat moral secara utuh. Artinya, upaya orang tua untuk menginternalisasikan nilai- nilai moral kedalam diri anak bukan hanya informasi tetapi juga ditangkap kebenarannya. ${ }^{16}$

Dalam ajaran agama islam dijelaskan bahwa pada dasarnya manusia itu baik dan memiliki potensi beragama, maka keluarga terlebih orang tualah yang akan mewarnai perkembangan anak. Orang tua hendaknya menciptakan lingkungan psikologis yang mendukung dalam pembentukan karakter anak dalam menjalankan aturan agama dan aturan masyarakat yang ada di lingkungannya. ${ }^{17}$ Dengan orang tua menerapkan bentuk- bentuk perhatian dengan tulus dan penuh kasih sayang, akan membuat anak menjadikan orang tua sebagai teladannya, sehingga dapat membantu peningkatkan perkembangan moral anak.

\section{PENUTUP}

Tingkat perhatian orang tua dari anak usia 7-12 tahun di Desa Durenan Kecamatan Sidorejo Magetan berada pada kategori sedang. Tingkat sedang menunjukkan orang tua cukup mampu menerapkan bentuk-bentuk perhatian kepada anak.

Peningkatan moral anak usia 7-12 tahun di Desa Durenan Kecamatan Sidorejo Magetan berada pada kategori sedang. Tingkat sedang menunjukkan bahwa anak telah memiliki peningkatan moral yang cukup baik dalam tiga ketegori peningkatannya yaitu pra konvensional, konvensional dan pasca konvensional.

\footnotetext{
${ }^{16}$ Moh Shochib, Pola Asuh Orang Tua Dalam Membantu Anak Mengembangkan Disiplin Diri (Jakarta: PT Rineka Cipta, 2000), 19.

${ }^{17}$ Ibid
} 
Terdapat hubungan yang signifikan antara perhatian orang tua usia 7-12 tahun di Desa Durenan Kecamatan Sidorejo Magetan dan peningkatan moral anak usia 7-12 tahun di Desa Durenan Kecamatan Sidorejo Magetan.

Disarankan bagi penelitian berikutnya untuk menambah variabel penelitian, subyek penelitian, dan memperluas lokasi penelitian yang kiranya berbeda karakteristik dengan penelitian ini. Disarankan peneliti selanjutnya hendaknya memperluas studi dengan mengikutsertakan berbagai faktor yang mempengaruhi aspek perhatian orang tua, seperti usia, latar belakang pendidikan, kondisi ekonomi keluarga, dan aspek lain yang berkaitan.

\section{DAFTAR RUJUKAN}

Hurlock, Elizabeth B. Psikologi Perkembangan. Jakarta: Erlangga, 1991.

Mustaqim. Psikologi Pendidikan.Yogjakarta: Pustaka belajar UIN Walisongo Semarang, 2008.

Nurichsan, Juntika dan Mubiar Agustin. Dinamika Perkembangan Anak dan Remaja: tinjau Psikologi, Pendidikan dan Bimbingan. Bandung: PT Refika Aditama, 2016.

Romlah. Psikologi Pendidikan. Malang: UMM Press, 2010.

Santoso, Singgih. Panduan Lengkap SPSS Versi 23. Jakarta: PT Alex Media Komputindo, 2016.

Shochib, Moh. Pola Asuh Orang Tua Dalam Membantu Anak Mengembangkan Disiplin Diri. Jakarta: PT Rineka Cipta, 2000.

Sugiyono. Metode Penelitian Kuantitatif, Kualitatis dan R\&D. Bandung: Alfabeta, 2016.

Sujarweni, V. Wiratna. SPSS Untuk Penelitian. Yogjakarta: Pustaka Baru, 2014.

Widyaningrum, Retno. Statistika. Yogjakarta: Pustaka Felicha, 2016. 